\title{
曲げを受ける柱の終局耐力式を用いた単層 2 万向格子シェルの断面設計 MEMBER PROPORTIONING OF TWO-WAY GRID SHELLS USING ULTIMATE STRENGTH FORMULA FOR BEAM-COLUMNS
}

\author{
山下哲 郎*，加 藤 史 郎** \\ Tetsuo YAMASHITA and Shiro KATO
}

\begin{abstract}
The present paper proposes a method for designing member sections in a two-way grid shell of single layer against a specified ultimate buckling load. The method is applicable for not only uniform but also unbalanced load. To consider significant bending effects explicitly, a strength formula for beam-columns that is given in the LSD recommendation of AJJ is adopted as the design formula. Moreover, to cope with the significant geometric nonlinear behavior, elastic nonlinear FEM analysis, which becomes easily available today, is applied as the principal tool for the method. The procedure is composed of three principal job steps. First, to obtain the gencralized slenderness, the preliminary elastic buckling analysis is performed in which the section of each member in an analyzed model is given proportionally to its axial force. Second, the stress analysis in which the section rigidities in the model are assumed to prevent the excessive geometric nonlinear effect at the design point is performed. Finally, the member sections are determined based on both the generalized slendemess and design stresses applying the ultimate strength formula for beam-columns.
\end{abstract}

Keywords: Two-way grid shells of single layer, Section design, Beam-column strength formula, Elastic nonlinear FEM analysis, Ultimate buckling strength, Unbalanced load

単層 2 方向格子シェル、断面設計、曲げを受ける柱の耐力式、弾性非線形有限要素解析、終局座屈強度、偏載荷重'

\section{1 はじめに}

近年、単層 2 方向格子シェル（注 1）が優れた意匠性から大ス パン屋根の構造体 りとして注目されているが、その構造設計におい ては必要な座屈耐力の確保が最も重要な課題であると考えられる。 当論文は設計条件として与えられた終局荷重（偏載荷重を含む）に 耐え得る単層 2 方向格子シェルの断面設計の論理を提案し、数值解 析によりその適用性を検証する。

既に単層 3 方向格子シェルについては、圧縮耐力曲線に基づく 弾塑性座屈耐力の評価法 2)基礎として、弾性 2 次解析を用いた断 面設計法 ${ }^{3.4)}$ や線形座屈解析を用いた方法 ${ }^{5}$ が提案されているが、2 方向格子シェルの座屈については研究が少なく、座屈特性に基づく 系統的な断面設計法は未だ提案されていない。

単層 2 方向格子シェルの座屈特性として、(1)座屈モードは全体 座屈で、個材座屈や節点座屈は発生しない 1,67,7)、(2)特に荷重の偏載 や形状初期不整が存在する場合、座屈前挙動に幾何学的非線形性が 顕著に表れ、最大荷重時の変形が大きい 7,89)、(3)非線形に増幅する 曲げモーメントの塑性化に対する影響が大きい、等が挙げられる。 これらに対応し、当設計法においては (1)断面設計に曲げを受ける柱 の耐力式 (建築学会鋼構造限界状態設計指針 ${ }^{10)}$ の設計式) を援用し、 曲げモーメントの影響を陽に考慮する。(2)部材の圧縮耐力は幾何学 的非線形性を考慮した弾性座屈解析を用いて定める正規化細長比よ
り計算し、シェルとしての全体座屈と幾何学的非線形性の影響を考 慮する。(3)設計荷重下の部材応力は弾性非線形解析を用いて得る。 近年、計算機の処理速度の急激な向上や沉用有限要素法ソフト の普及から非線形解析は利用しやすい環境になりつうあるが、材料 学的及び幾何学的非線形性の双方を考慮した弾塑性非線形解析は今 日でも計算時間や解の収束性の点で問題が多く、適用には経験が必 要であり設計奏務に使用するには抵抗がある（注 2 ）。従って計算時 間、収束精度とも弾塑性非線形解析と比べて格段に有利な弾性非線 形解析を主なツールとして用いる。これに対応し、設計法のプロセ スを、正規化細長比を得るための「予備解析」 $\rightarrow$ 設計応力を計算す る「応力解析」 $\rightarrow$ 「断面設計」の 3 段階より構成し、非線形解析と 断面設計の繰り返しによる収束計算を避け、沉用有限要素法ソフト を利用しやすい方法とした。

論文は最初に設計法の力学的根拠を論じる。重点として(1)解析 モデルの断面積は軸力に比例して定める、(2)部材の弾塑性圧縮耐力 には修正 Dunkerley 式 2)を用いるが、偏載荷重に対しては軸力のみを 用いた酎力評価は危険側となる、(3)応力解析用モデルの断面は設計 断面の剛性を予測して定める、等を説明する。次に試設計モデルの 弾塑性座屈解析を行い設計法の適用性を検証する。更に、弾塑性座 屈荷重の初期不整敏感性を曲げモーメントの影響との関連において 評価し、設計における初期不整の取り扱いについて考察する。
* 侏巴コーポレーション技術開発部・工修

** 豊橋技術科学大学 教授.工博
Engineering Development Division, Tomoe Corporation, M. Eng. Prof., Toyohashi University of Technology, Dr. Eng. 


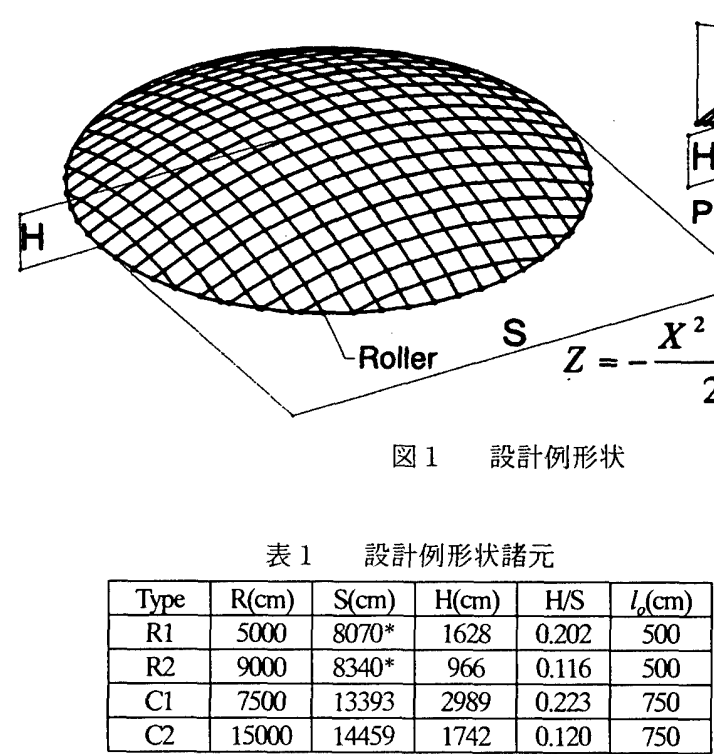

（*：対角線方向スパンを表示）

\section{2 試設計例}

当断面設計法の対象は以下に記述する試設計例と類似の剛接合 単層 2 方向格子シェルである。

\section{2-1 形状、境界条件}

対象構造物は 2 方向の主曲率が等しく、部材長がほぼ等しくなるよう グリッドが定められた扁平な単層 2 万向格子シェルである。境界剛性や形 状の影響を考慮するため、設計例として正方形平面(Type R)と円形平面 (Type C)の 2 種類の形状を想定し（図 1)、それぞれに2 種類のプロポーシ ヨンを与えた (表 1)。ともに鉛直面内の放物線を座標軸に平行移動させて 形状を形成する。形状関数（図 1 内付記）のRは近似的に曲率半径となる。 節点座標は、水平投影面にて部材が $X, Y$ 座標軸に平行となり(Type Cのリ ング及びリング周辺を除く)、かつ部材実長 $l_{o}$ が、Type Rは $5 \mathrm{~m}$, Type Cは $7.5 \mathrm{~m}$ （リンク及びリング周辺を除く）となるよう定める。境界条件はType $\mathrm{R}$ をピン支持、テンションリングを有する Type Cをローラー支持とする。

\section{2-2 部材断面、接合条件、材料}

部材断面は円形管とする。管径 $D$ は式(1)を用いて部材長 $l_{o}$ と細 長比 $\lambda_{o}$ 加ら定める。

$$
D=\frac{2 \sqrt{2} l_{o}}{\lambda_{o}}
$$

設計例では $\lambda_{0}=20,40$ の 2 種類を想定する。管径はテンションリン グを含む全部材について均一とし、各部材の肉厚 $t$ を設計対象とす る。局部座屈の問題は無視し、径厚比は制限しない。

接合部の曲げ剛性は座屈挙動に大きな影響を及ぼすと考えられ るが、今回の設計例では完全剛接合を仮定する。完全剛接を仮定で きない接合部ディテールに対して、実験等で評価した接合部剛性を 用いて設計する方法の開発が今後の課題として残る。

構造材料にはシエル部材に降伏応力 $\sigma_{y}^{(s)}=235 \mathrm{~N} / \mathrm{mm}^{2} 、$ Type Cの テンションリング部材には $\sigma_{y}{ }^{(r)}=440 \mathrm{~N} / \mathrm{mm}^{2}$ の鋼材を想定した。ヤン

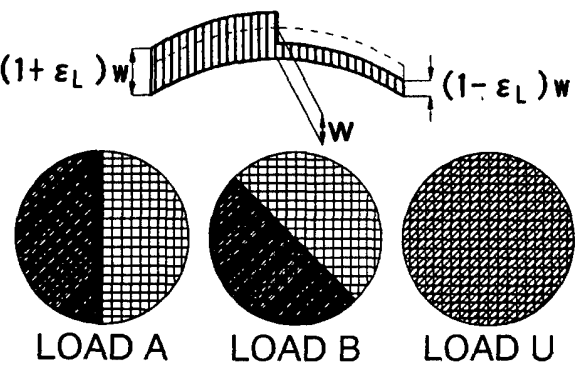

図 2 荷重条件

\section{図 3 初期不整量}

グ係数 $\mathrm{E}=2.06 \times 10^{6} \mathrm{~N} / \mathrm{mm}^{2}$ 、せん断弾性係数 $\mathrm{G}=7.94 \times 10^{5} \mathrm{~N} / \mathrm{mm}^{2}$ とする。

\section{2-3 荷重}

建築物の屋根構造体として設計する場合、積雪等による偏載荷 重を考慮する必要がある。図 2 に試設計例で想定する荷重モード(等 分布 $\mathrm{U}$ 、偏載 $\mathrm{A}, \mathrm{B})$ 、荷重強度 $w$ 及び偏載の程度を示す係数 $\varepsilon_{L}$ の定 義を示す。試設計例では $\varepsilon_{L}=0.5$ とする。

\section{2-4 形状初期不整}

単層格子シェルの座屈耐力は形状初期不整により時に大きく低 市するため、これを設計に考虑する必要がある。完全形からの面外 最大偏差量 $e_{o}$ を設計用初期不整量とする（図 3)。既往の研究では、 力学的観点から等価連続体板厚 $t_{e}$ を基準として $e_{o}$ を想定する場合が 多い $2.5,13,16)$ が、実際の初期不整は施工上の原因で発生すると考えら れる。試設計では、例えば高さ方向の計測誤差により発生すると仮 定し、ドームのライズ $\mathrm{H}$ を基準として $e_{o}=\mathrm{H} / 200$ とする。この值は 実際に建設された $200 \mathrm{~m}$ 級単層 3 方向格子シェルの初期不整量の推 定值である $e_{o}=5 \mathrm{~cm}^{11)}$ の 1 3 倍程度となり（表 2)、一般的な鉄骨構 造の許容施工誤差 ${ }^{12)}$ をきく越えているが、初期不整の影響を明確 にするために大き目の値を仮定した。

初期不整の形状は座屈荷重の低下に対する影響が大きいと考え られる線形座屈 1 次モード比例形を仮定するが、この形状の初期不 整が必ずしも弾塑性座屈荷重の下限値を与えるとは限らない(3)。よ り合理的な初期不整の影響評価は今後の研究課題の一つである。

\section{$2-5$ 利用する有限要素法ソフトウェア}

設計に必要な数值解析は、線形解析、線形座屈固有値解析及び 幾何学的非線形性を考慮した弾性非線形解析である。ここではこれ らの解析に汎用有限要素法ソフトウェア $\mathrm{ADINA}^{141}$ を用いる。当ソ フトウェアは幾何学的非線形性を Updated Lagrangian 法により導入 し、弧長增分法により釣合経路を追跡する。各增分ステップにおい ては収束計算が行われる。1 部材を軸力と曲げモーメントの相互作 用が考慮された 1 本の Beam-column 要素でモデル化する。また設計 結果の検証のため弾塑性非線形解析を行う。このとき材料モデルは 等方性完全弾塑性体で、ひずみ硬化を無視して理想化したバイリニ ア形の応力・歪関係を仮定し、Mises の降伏条件を用いる。 


\section{$2-6$ 設計例の表示}

図 4 に設計例の表示方法を示す。形状、部材細長比、初期不整 量、荷重条件に関する情報が表現される。表 2 に設計例について想 定した設計条件をまとめて示す。

\section{3 設計法}

\section{$3-1$ 概要}

当設計法では、既に発表された単層 3 方向格子シェルの断面設 計法 ${ }^{3,45}$ ) 同様、各部材の軸力を正規化細長比から計算する圧縮耐 力に照合して座屈に対する断面設計を行う。また曲げ、ねじりモー メントを陽に評価して塑性化のチェックを行う。これらの計算には 鋼構造限界状態設計指針 ${ }^{10)}$ の曲げを受ける柱の終局耐力式を援用す る。

また既往の設計法 ${ }^{3,4,5)}$ では、線形座屈解析または弾性 2 次解析と 断面設計の繰り返しによる収束計算を用いて断面を定めるが、ここ では、正規化細長比を定める予備解析 $\rightarrow$ 応力解析 $\rightarrow$ 断面設計、の 3 段階で設計プロセスを構成して非線形解析を計 2 回とし、汎用有限 要素法解析ソフトを利用しやすい方法とした。

\section{3-2 予備解析と弾性座屈而力}

予備解析は正規化細長比を定めるための線形応力解析及び弾性 座屈解析からなる。弾性座屈耐力を確保するため予備解析モデルの 断面は軸力に比例させる。以下その力学的根拠と正規化細長比の定 め方を論じる。

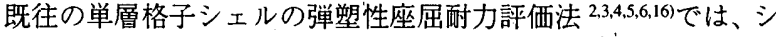
エルの座屈特性を代表する部材（以後「特定部材」と呼び、その属 性を上添字(m)で示す) を選択し、その軸力を用いて正規化細長比を

\section{表 2 設計条件}

\begin{tabular}{|c|c|c|c|c|c|c|c|c|c|c|}
\hline Model & $\begin{array}{l}\text { Config } \\
\text { uration }\end{array}$ & $\lambda_{0}$ & $\begin{array}{c}D \\
(\mathrm{~cm})\end{array}$ & $\begin{array}{c}e_{o} \\
(\mathrm{~cm}) \\
\left(e_{0} / t_{e l}\right)\end{array}$ & $\begin{array}{c}w_{d} \\
\left(\mathrm{KN} / \mathrm{m}^{2}\right)\end{array}$ & $\begin{array}{c}\sigma_{y}{ }^{(s)} \\
\left(\mathrm{N} / \mathrm{mm}^{2}\right)\end{array}$ & $\begin{array}{c}\sigma_{y}{ }^{(r)} \\
\left(\mathrm{N} / \mathrm{mm}^{2}\right)\end{array}$ & Boundary & $\begin{array}{l}\text { Load } \\
\text { pettern }\end{array}$ & $\varepsilon_{L}$ \\
\hline R1_20_U & \multirow{3}{*}{ R1, } & \multirow{3}{*}{20} & \multirow{3}{*}{70.71} & \multirow{3}{*}{$\begin{array}{c}8.14 \\
(0.094)\end{array}$} & \multirow{3}{*}{9.8} & \multirow{3}{*}{235} & \multirow{3}{*}{ - } & \multirow{3}{*}{ Pin } & $\mathrm{U}$ & - \\
\hline $\mathrm{R} 1$ 20_A05 & & & & & & & & & A & 0.5 \\
\hline R1_20_B05 & & & & & & & & & $\mathrm{B}$ & 0.5 \\
\hline R1_40_U & \multirow{3}{*}{$\mathrm{R} 1$} & \multirow{3}{*}{40} & \multirow{3}{*}{35.36} & \multirow{3}{*}{$\begin{array}{c}8.14 \\
(0.19)\end{array}$} & \multirow{3}{*}{9.8} & \multirow{3}{*}{235} & \multirow{3}{*}{-} & \multirow{3}{*}{ Pin } & $\mathrm{U}$ & - \\
\hline R1_40_A05 & & & & & & & & & $\mathrm{A}$ & 0.5 \\
\hline $\mathrm{R} 1 \_40 \_\mathrm{B} 05$ & & & & & & & & & $\mathrm{~B}$ & 0.5 \\
\hline $\mathrm{R} 2 \_20 \_\mathrm{U}$ & \multirow{3}{*}{ R2 } & \multirow{3}{*}{20} & \multirow{3}{*}{70.71} & \multirow{3}{*}{$\begin{array}{c}4.83 \\
(0.056)\end{array}$} & \multirow{3}{*}{9.8} & \multirow{3}{*}{235} & \multirow{3}{*}{ - } & \multirow{3}{*}{ Pin } & $\mathrm{U}$ & - \\
\hline $\mathrm{R} 2 \_20 \_\mathrm{A} 05$ & & & & & & & & & A & 0.5 \\
\hline R2_20_B05 & & & & & & & & & B & 0.5 \\
\hline R2_40_U & \multirow{3}{*}{$\mathrm{R} 2$} & \multirow{3}{*}{40} & \multirow{3}{*}{35.36} & \multirow{3}{*}{$\begin{array}{c}4.83 \\
(0.11)\end{array}$} & \multirow{3}{*}{9.8 . } & \multirow{3}{*}{235} & & & $\bar{U}$ & - \\
\hline R2_40_A05 & & & & & & & & Pin & A & 0.5 \\
\hline R2_40_B05 & & & & & & & & & B & 0.5 \\
\hline C1_20_U & & & & & & & & & $\mathrm{U}$ & - \\
\hline C1_20_A05 & $\mathrm{Cl}$ & 20 & 106.1 & (01) & 4.9 & 235 & 440 & Roller & A & 0.5 \\
\hline C1_20_B05 & & & & & & & & & B & 0.5 \\
\hline C1_40_U & & & & & & & & & $\mathrm{U}$ & - \\
\hline C1_40_A05 & $\mathrm{Cl}$ & 40 & 53.03 & $(0.23)$ & 4.9 & 235 & 440 & Roller & A & 0.5 \\
\hline C1_40_B05 & & & & & & & & & B & 0.5 \\
\hline C2_20_U & & & & & & & & & $\bar{U}$ & - \\
\hline C2_20_A05 & $\mathrm{C} 2$ & 20 & 106.1 & $(0.067)$ & 4.9 & 235 & 440 & Roller & A & 0.5 \\
\hline C2_20_B05 & & & & & & & & & B & 0.5 \\
\hline C2_40_U & & & & & & & & & $\mathrm{U}$ & - \\
\hline C2_40_A05 & $\mathrm{C} 2$ & 40 & 53.03 & $(0.13)$ & 4.9 & 235 & 440 & Roller & A & 0.5 \\
\hline C2_40_B05 & & & & & & & & & $\mathrm{B}$ & 0.5 \\
\hline
\end{tabular}

定義する。

$$
\Lambda_{e} \equiv \sqrt{\frac{N_{p}^{(m)}}{\alpha_{o} N_{c r}^{\operatorname{lin}(m)}}}
$$

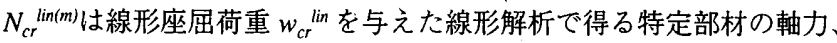
$N_{p}^{(m)}$ は同部材の全塑性軸力である。特定部材には比 $N_{p} / N_{c r}$ lin が最小値 となる圧縮部材を選択する。 $\alpha_{0}$ は式(3)で定義される座屈低隇係数 である。

$$
\alpha_{o} \equiv \frac{w_{c r}^{e}}{w_{c r}^{l i n}}
$$

$w_{c r}{ }^{e}$ は幾何学的非線形を考慮した弾性座屈荷重である。当設計法で は、 $\Lambda_{e}$ の計算に予備解析結果. (上添字 pre で示す) を用いる。

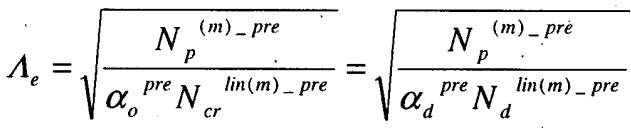

$N_{d}^{\text {lin }(m) \perp \text { re }}$ は設計荷重を与えた線形解析で得る特定部材の軸力である。 $\alpha$ pre は式(5)で定義される。

$$
\alpha_{d}^{p r e} \equiv \frac{w_{c r}{ }^{e_{-}}{ }^{p r e}}{w_{d}}
$$

弾性座屈に対しては、部材毎に式(6)を適用して断面を設計する。

$$
N_{c r^{\prime}}^{e(i)} \geq N_{d}^{(i)_{-} s t r}
$$

$N_{d}^{(i) \_s r}$ は設計荷重 $w_{d}$ 下の i 部材（属性を上添字(i)で示す）の部材圧縮 軸力で、後述の応力解析結果（上添字 sirで示す）を用いる。 $N_{c r}{ }^{e(i)}$ は $\Lambda_{e}$ およ゙全塑性軸力 $N_{p}^{(i)}$ より次式を 用いて計算される弾性座屈耐力である。 (図 5)。

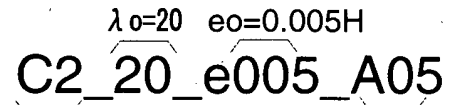

Configuration: $\mathrm{C} 2$ Load type A $\varepsilon_{L}=0.5$

図 4 設計例の表示

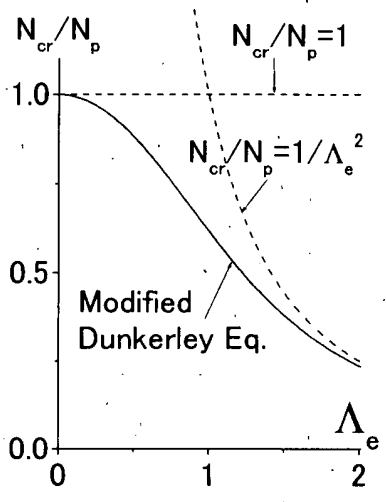

図 5 各種圧縮耐力曲線 


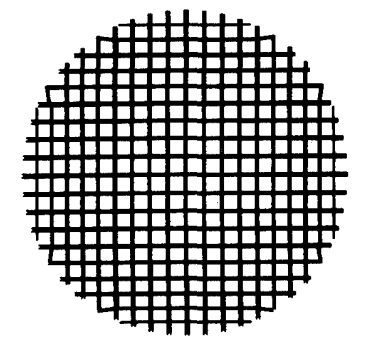

荷重 U

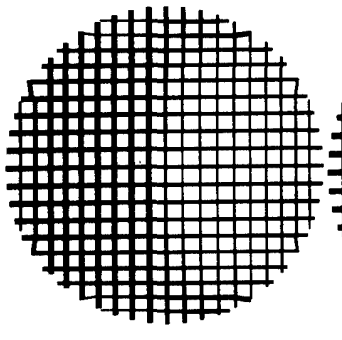

荷重 A

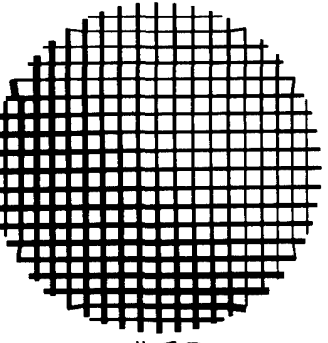

荷重B

図 6 軸力分布の例（C1_40_e0、シェル部材のみ表示）

$$
\frac{N_{c r}{ }^{e(i)}}{N_{p}{ }^{(i)}}=\frac{1}{\Lambda_{e}{ }^{2}}
$$

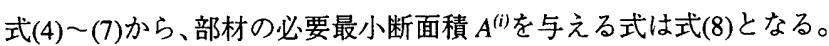

$$
A^{(i)}=\frac{1}{\alpha_{d}{ }^{p r e}} \cdot \frac{N_{d}^{(i)_{-} s t r}}{N_{d}{ }^{\text {lin(m) }}{ }^{\text {pre }}} A^{(m)_{-} \text {pre }}
$$

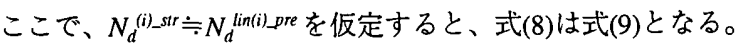

$$
A^{(i)}=\frac{1}{\alpha_{d}{ }^{p r e}} \cdot \frac{N_{d}^{\text {lin(i)_pre }}}{N_{d}^{\text {lin(m)_pre }}} A^{(m)_{-} \text {pre }}
$$

いま予備解析モデルにおいて軸力と断面積の比例関係が全シェ ル部材について成立しているとすると、

$$
\frac{A^{(m)_{-} \text {pre }}}{N_{d}^{\operatorname{lin}(m)_{-} \text {pre }}}=\frac{A^{(i)}-\text { pre }}{N_{d}^{\operatorname{lin}(i)_{-} \text {pre }}}
$$

であるため、断面の設計式は式(10)となる。

$$
A^{(i)}=\frac{1}{\alpha_{d}^{p r e}} A^{(i)-p r e}
$$

式(10)は弾性座屈耐力を確保し得る必要最小断面設計式であり、 弾性座屈荷重と各部材断面積の単純比例関係を表している。参考に 軸力分布（即ち断面積分布）の例を図 6 に示す。

シェル部材の軸力と断面積の比例関係は式(11)で定める。

$$
A^{(i)_{-} p r e}=\frac{N_{d}^{l i n(i)_{-} p r e}}{\sigma_{y}^{(s)}} \Lambda_{c}{ }^{2}
$$

このとき特定部材を選択する必要はなくなり、正規化細長比の表現 は式(12)のように簡略化される。

$$
\Lambda_{e}=\sqrt{\frac{\sigma_{y}^{(s)} A^{(m)_{-} p r e}}{\alpha_{d}{ }^{p r e} N_{d}{ }^{l i n(m)_{-} p r e}}}=\frac{\Lambda_{c}}{\sqrt{\alpha_{d}{ }^{p r e}}}
$$

$\Lambda_{c}$ は等分布荷重を受ける均一断面シェルの連続体法に基づく正規 化細長比の略算值 ${ }^{15)}$ で、設計断面と尒備解析の断面が極端に異なる ことを避けるために導入する。

$$
\Lambda_{c}=\lambda_{o} \sqrt{\frac{R \sigma_{y}{ }^{(s)}}{9.2 \psi E l_{o}}}, \quad \psi=1+4\left(\frac{H}{S}\right)^{2}
$$

仮に予備解析モデルの断面を全部材均一 $\left(A^{(i) D r r}=A^{(m) \_p r e ~}\right)$ とした

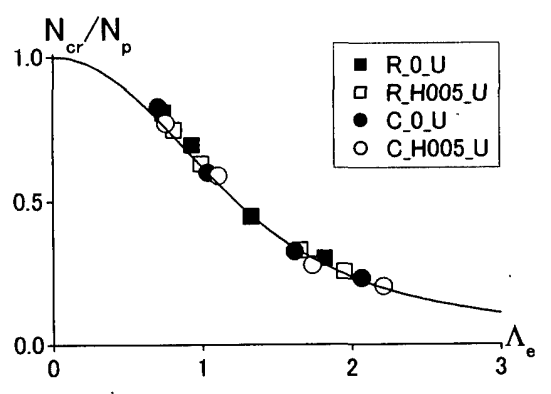

図 7 弾塑性圧縮酎力（等分布荷重）
場合には、断面設計式は式(14)となる。

$$
A^{(i)}=\frac{1}{\alpha_{d}^{p r e}} \cdot \frac{N_{d}^{\operatorname{lin}(i)_{-} \text {pre }}}{N_{d}^{\operatorname{lin}(m)_{-} \text {pre }}} A^{(i)_{-} \text {pre }}
$$

しかしながら、特定部材の定義から式(14)右辺の $N_{d}^{\text {lin(i) } \perp \text { re }} / N_{d}^{\text {lin(m)_pre }}$ $\leqq 1$ (等号成立は軸力も均一に分布する場合) となり、式(10)との比 較から弾性座屈耐力は必ずしも確保されないことがわかる。

なお、設計式は直接には断面積を与えるが、2 方向格子シェル

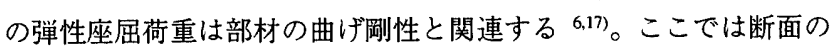
径を固定し肉厚を設計対象としているため断面積と曲げ剛性はほほ 比例し、弾性座屈酎力の確保に問題はないが、断面設計の際予備解 析で仮定した断面の径を変更する場合は注意が必要である。

シェル内部の引張材（今回の試設計例では極めて少ない）及び Type C のテンションリング部材については、式(15)で予備解析断面 を定める。

$$
A^{(i)_{-} p r e}=\frac{N_{d}^{\operatorname{lin}(i)_{-} p r e}}{\sigma_{y}^{(r)}}
$$

\section{3-3 弾塑性圧縮耐力}

弾塑性座屈に対しては、式(6)と全塑性軸力を正規化細長比をパ ラメータに連続させた圧縮耐力曲線を用いて断面を定める（図 5)。 柱の場合、曲げを受けない単純圧縮柱の実験結果から初期不整等の 影響を考慮して圧縮耐力曲線の形が定められているが、ここでは単 純圧縮状態に代わるものとして曲げの影響の少ない等分布荷重に対 する膜応力状態を想定し、数值実験により曲線の形状を定める。

図 7 は等分布荷重に対する設計例（後述）の予備解析モデルの 弾塑性座屈解析結果である。モデル断面を軸力に比例させて設定し た方法は補足にて説明する。Type Cの解析ではテンションリングを 弾性と仮定した。解析結果の図上へのプロットに際しては、横軸に 式(12)、縦軸には荷重と軸力との線形関係を仮定し式(11)から導かれ る式(16)を用いる。

$$
\frac{N_{c r}}{N_{p}}=\frac{w_{c r}^{p r e}}{w_{d} \Lambda_{c}{ }^{2}}
$$

$w_{c r}^{\text {pre }}$ は弾塑性座屈荷重である。形状初期不整を与えるモデルについ ては、断面は完全形モデルと同じとし、弾性及び弾塑性座屈解析を 不整形モデルで行い横軸、縦軸双方の值に影響を考慮している。ま た表 3 に座屈低隇係数を示す。偏載荷重を受ける場合、初期不整が 
表 3 予備解析モデルの座屈低減係数

\begin{tabular}{|l|cc|l|cc|}
\hline \multicolumn{1}{|c|}{$\mathrm{e}_{\mathrm{o}}}$. & 0 & $0.005 \mathrm{H}$ & \multicolumn{1}{|c|}{$\mathrm{e}_{\mathrm{o}}$} & 0 & $0.005 \mathrm{H}$ \\
\hline R1_20_U & 0.94 & 0.78 & C1_20_U & 0.87 & 0.76 \\
R1_20_A05 & 0.88 & 0.74 & C1_20_A05 & 0.69 & 0.65 \\
R1_20_B05 & 0.94 & 0.85 & C1_20_B05 & 0.84 & 0.77 \\
\hline R1_40_U & 1.00 & 0.82 & C1_40_U & 0.90 & 0.78 \\
R1_40_A05 & 1.01 & 0.92 & C1_40_A05 & 0.88 & 0.81 \\
R1_40_B05 & 0.96 & 0.96 & C1_40_B05 & 0.88 & 0.79 \\
\hline R2_20_U & 0.89 & 0.78 & C2_20_U & 0.91 & 0.80 \\
R2_20_A05 & 0.90 & 0.79 & C2_20_A05 & 0.80 & 0.68 \\
R2_20_B05 & 0.93 & 0.83 & C2_20_B05 & 0.72 & 0.68 \\
\hline R2_40_U & 0.99 & 0.86 & C2_40_U & 0.93 & 0.81 \\
R2_40_A05 & 1.00 & 0.94 & C2_40_A05 & 0.79 & 0.69 \\
R2_40_B05 & 1.11 & 0.89 & C2_40_B05 & 0.76 & 0.71 \\
\hline
\end{tabular}

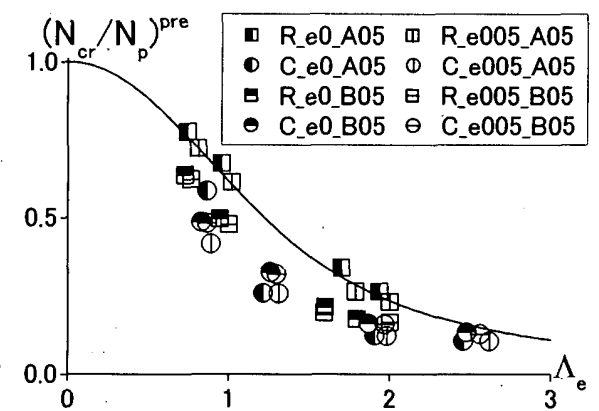

図 8 弾塑性圧縮酎力（偏載）

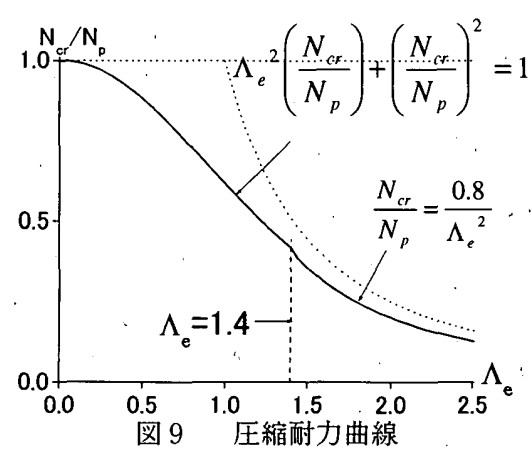

\section{Stress Unstable zone}

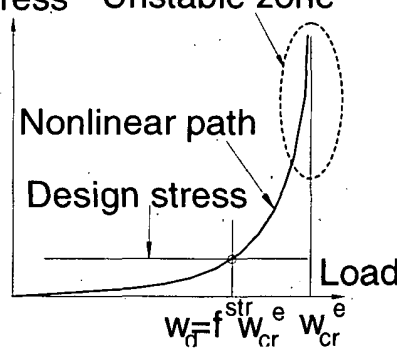

図 10 設計点と弾性座屈荷重

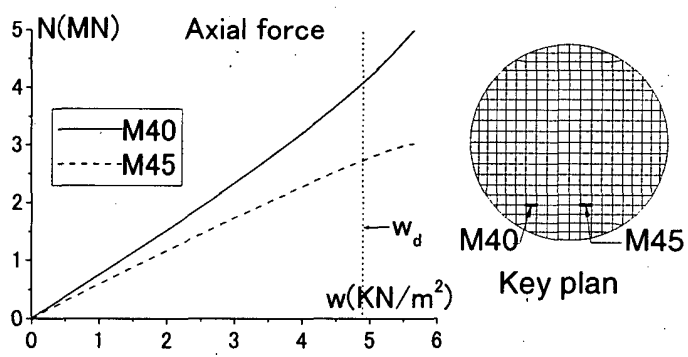

図 11 荷重と部材応力の関係 (C2_40_A05)

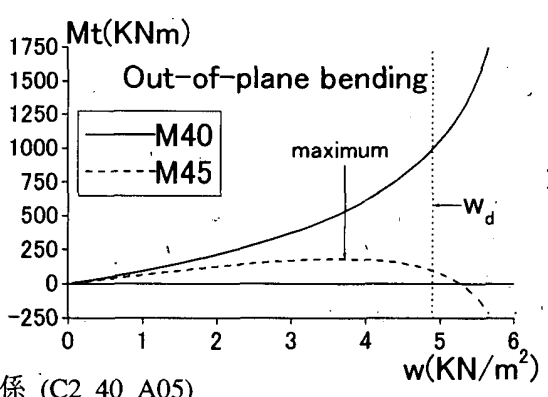

なくとも弾性座屈荷重は線形座屈荷重を大きく下回る場合がある。

図 7 の曲線は加藤他が単層 3 方向格子シェルの圧縮耐力曲線と して提案した 2 修正 Dunkerley 式(17)であり、等分布荷重を受ける均 一断面 2 方向格子シェルヘの適用性も確認されている ${ }^{16.17) 。 ~}$

$$
\Lambda_{e}^{2}\left(\frac{N_{c r}}{N_{p}}\right)+\left(\frac{N_{c r}}{N_{p}}\right)^{2}=1
$$

この曲線は初期不整の有無に拘わらず解析結果を精度良く近似 するため、压縮耐力曲線として採用する。

\section{$3-4$ シェル部材の断面設計式}

図 8 は偏載荷重を受げる予備解析モデルの弾塑性座屈解析結果 を図 7 と同様にプロットしたものである。単層 3 方向格子シェルの 場合、偏載荷重を受ける場合でも式(17)の曲線で精度良く弾塑性座 屈耐力を近似できるが 5)、今回は多くの場合弾塑性座屈耐力は式(17) の曲線を大幅に下回っている。これは偏載荷重時に強く発生する曲 げモーメントの断面の塑性化に及ぼす影響によるものと考えられる。 その影響を陽に考慮するため、断面設計には曲げを受ける柱の耐力

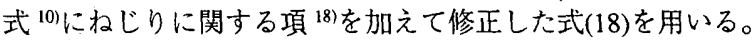

$\frac{N_{d}{ }^{(i)_{-} s t r}}{N_{c r}{ }^{(i)}} \leq 1, \quad \frac{N_{d}{ }^{(i)_{-} s t r}}{N_{p}{ }^{(i)}}+\frac{0.85 M_{d}{ }^{(i)_{-} s t r}}{M_{p}{ }^{(i)}}+\frac{T_{d}{ }^{(i)}{ }_{-} s t r}{T_{p}{ }^{(i)}} \leq 1$ (18)

シェル内部の引張部材の断面設計には式(19)を用いる。

$\frac{N_{d}}{N_{p}}+\frac{0.85 M_{d}}{M_{p}}+\frac{T_{d}}{T_{p}} \leq 1$

部材の庄縮耐力 $N_{c r}^{(i)}$ には、式(17)を応力解析における設計点 (後
述）を考慮して修正した式(20)を用いる（図 9)。

$$
\frac{N_{c r}{ }^{(i)}}{N_{p}{ }^{(i)}}=\left\{\begin{array}{cc}
\frac{-\Lambda_{e}{ }^{2}+\sqrt{\Lambda_{e}{ }^{4}+4}}{2} & \left(\Lambda_{e}<1.4\right) \\
\frac{0.8}{\Lambda_{e}{ }^{2}} \quad\left(\Lambda_{e:} \geq 1.4\right) & \left.{ }^{2}\right)
\end{array}\right.
$$

\section{3-5 テンションリング部材の設計}

Type Cについては、周辺のテンションリングがシェルの座屈に 先行して降伏すると構造全体の耐荷力はそれ以上上昇しない。この 点を考慮し、テンションリングの部材断面設計式には余裕係数 $\Phi_{r}$ を導入する。

$$
\frac{N_{d}}{N_{p}}+\frac{0.85 M_{d}}{M_{p}}+\frac{T_{d}}{T_{p}} \leq \frac{1}{\Phi_{r}}
$$

$\Phi_{r}$ の值については後に考察する。

\section{3-6 応力解析モデル}

挙動の幾何学的非線形性を無視できないため弾性非線形解析を 用いて設計応力を求めるが、解析で仮定する断面剛性より設計断面 の剛性が低いと設計点における非線形性を過小評価する恐れがある。 従って設計断面の剛性を安全側に（設計断面より若千低く）予測し て子備解析モデルの断面を修正し、応力解析モデルの断面とする。

応力解析モデルのシエル部材の断面積 $A^{(i) \text { SIr }}$ は式(22)で定める。

$$
A^{(i)_{-}{ }^{\prime} s t}=\frac{1}{f^{s t r} \alpha_{d}^{p r e}} A^{(i)_{-} \text {pre }}
$$

$f^{\prime \prime r}$ は弾性座屈点に対する設計点の位置を定める係数であり（図 10）、 修正 Dunkerley 式に基づく弾塑性座屈耐力（近似的に設計点とみな 


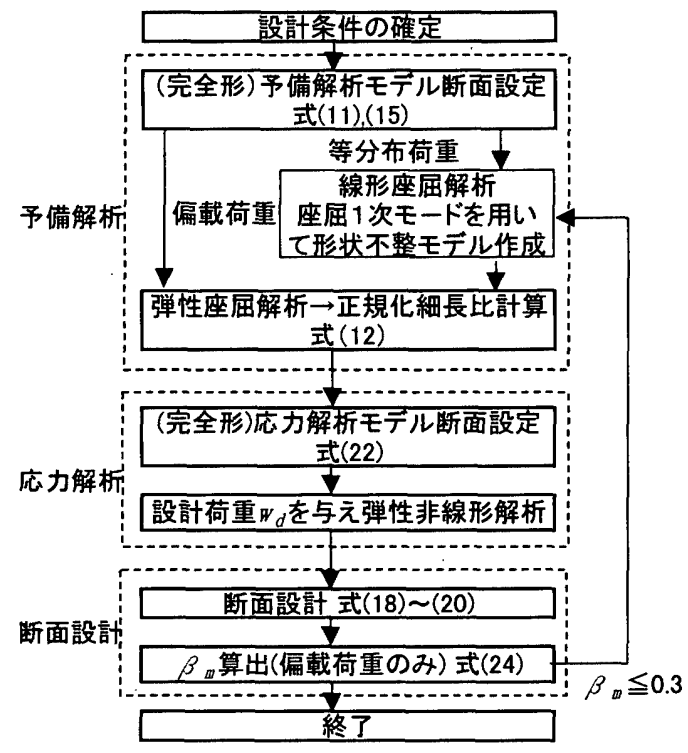

図 12 設計プロセス

す）と弾性座屈耐力の比として正規化細長比より計算する。

$$
f^{s t r}=\left\{\begin{array}{c}
\frac{-\Lambda_{e}{ }^{2}+\sqrt{\Lambda_{e}{ }^{4}+4}}{2} / \frac{1}{\Lambda_{e}{ }^{2}} \\
0.8 \quad\left(\Lambda_{e}>1.4\right)
\end{array}\left(\Lambda_{e} \leq 1.4\right)\right.
$$

前述のように偏載荷重に対して修正 Dunkerley 式の精度は良く ないが、この場合応力解析モデルの剛性は曲げモーメントの影響を 考慮した設計断面より小さく、即ち安全側に設定することになるた め式(23)をそのまま用いる。また $\Lambda_{e}$ が大きく、弾性座屈で耐力が決 まる場合設計点が弾性座屈点近傍の極端に非線形性の強い挙動とな

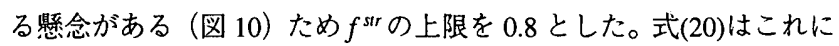
対応して圧縮耐力が弾性座屈酎力の 0.8 倍以下となるよう压縮耐力 曲線を設定したものである（ $f^{s t r}=0.8$ は $\Lambda_{e}=1.4$ に対応する）。

Type C のテンションリング部材断面は予備解析断面をそのまま 用いることにする。

図 11 に荷重と部材応力の関係の例を示す。部材の軸力は偏載荷
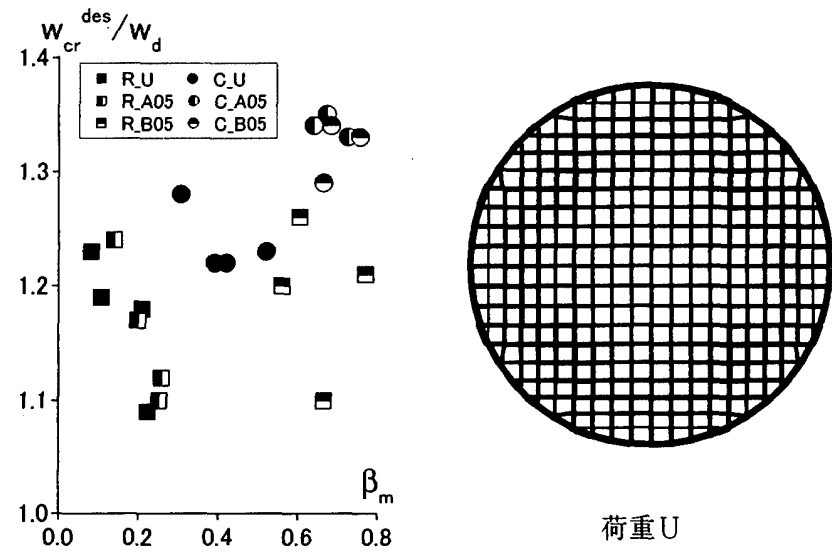

荷重 U
重下でも弾性座屈点近傍まで荷重とほぼ線形関係を保つが、曲げ及 びねじりモーメントの非線形性は特に偏載荷重下において著しい。 中には設計荷重より低い荷重で曲げモーメントが最大值となる部材 （図 11、M45）もあるが、このような部材についても設計荷重にお ける応力を用いて断面設計する。

\section{3-7 設計プロセスのまとめ}

図 12 に断面設計プロセスをまとめてフローチャートで示す。形 状初期不整を考慮する場合、その影響を正規化細長比に反映するた め、完全形モデルで予備解析断面を定める $\rightarrow$ 線形座屈解析で 1 次座 屈モードを得る $\rightarrow$ 形状不整モデルを作成 $\rightarrow$ 形状不整モデルで弾性座 屈解析 $\rightarrow$ 正規化細長比の計算、というプロセスを適用する。初期不 整を考慮する基準については次章で考察する。

\section{4 座届耐力の検証}

設計法の適用性を試設計例の数值実験(弾塑性座屈解析)によっ て検証すると共に、初期不整の影響について考察する。尚、4-1 及 び4-2においては、シェルそのものの座屈耐力を論じるためテンシ ヨンリングを弾性として数值実験を行う。

\section{4-1 完全形モデルの弾塑性座屆耐力}

以下試設計例の弾塑性座屈荷重の設計荷重に対する比を余裕度 と呼ぶ。初期不整を考慮せず断面設計を行った場合 $\left(\Phi_{r}=1.2\right)$ の余裕 度 $w_{c r}{ }^{d e s} / w_{d}$ を図 13 に示す。余裕度の平均は 1.24 、標準偏差は 0.09 であり、当設計法は精度良く設計荷重を満足する断面を与えること がわかる。グラフの横軸は式(24)で定義される設計断面に対する曲 げモーメントの影響を表す係数 $\beta_{m}$ であり、次に述べるように初期 不整敏感度と相関の強いファクターである。

$$
\beta_{m} \equiv\left(\frac{0.85 M_{d}}{M_{p}}+\frac{T_{d}}{T_{p}}\right)_{a v r_{-}(s)}
$$

下添字 ${ }_{a r}(s)$ は全シェル部材の平均値であることを意味する。図 14 に設計断面分布の例を示す。

\section{4-2 形状初期不整の影響評価}

4-1 で断面設計したモデルに形状初期不整を与えて弾塑性座屈荷

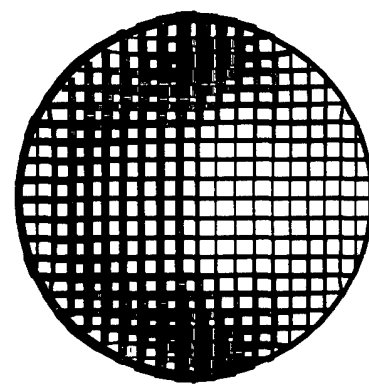

荷重A

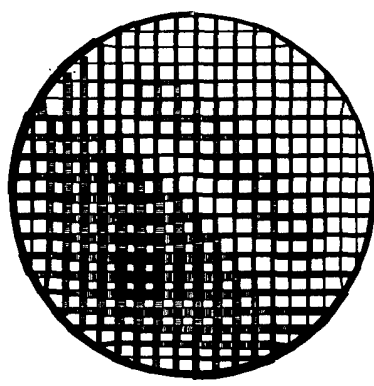

荷重 B 


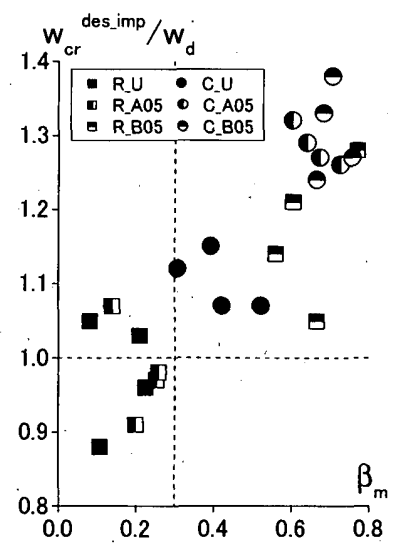

図 15 余裕度 $\left(w_{c r}^{\left.\text {des_imp } / w_{d}\right)}\right.$

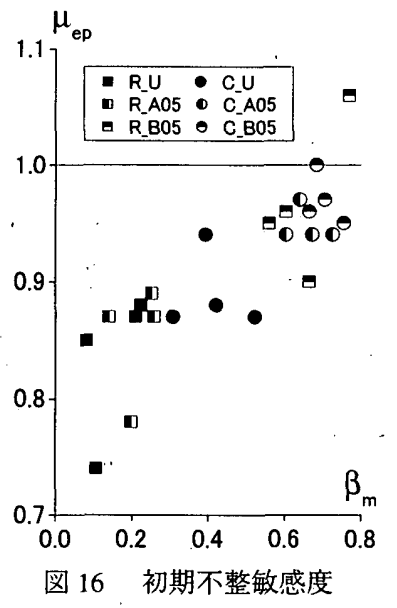

図 16 初期不整敏感度
重の初期不整敏感性を調べる。図 15 に形状不整モデルの余裕度

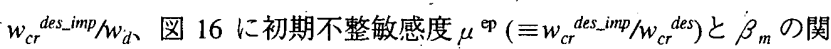
連を示す。 $\beta_{m}$ の值、すなわち曲げモーメントの影響の小さいケー ス(R_U,R_A05)では、もともと余裕度が低い上に初期不整敏感度も 高く、弾塑性座屈荷重の多くが設計荷重を下回っている。

上の数值実験結果に基づき、初期不整が発生し得る場合、以下の 設計ルールを定める“(適用範囲は $e_{0}=H / 200$ 以下)。

・等分布荷重については必ず初期不整を考慮して断面設計する。

・偏载荷重にういては一度完全形で断面設計を行い、 $\beta_{m} \leqq 0.3$ なら ば初期不整を考慮して再設計を行う。

以上のルールを適用して再度断面設計したモデルの余裕度 $\left(w_{c r}^{\text {des_rev }} / w_{d}\right)$ を図 17、そのヒストグラムを図 18 に示す。これらの図 から、当設計プロセスにより、設計終局荷重に対して良好な精度で かつ安全側に断面設計できることがわかる。

\section{4-3 テンションリングの引張耐力}

Type Cのテンションリングの材料を弾塑性として解析した結果 を表 4 に示す。ここでは初期不整は考慮しない。

$\Phi_{r}=1.0$ として断面設計した場合、弾塑性座屈荷重 $w_{c r}^{r}$ l. 1.0 はテン

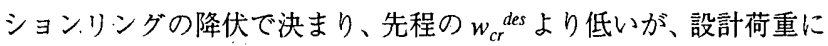
対しては概して約 1 割の余裕を有している。 $\Phi_{r}=1.2$ の場合、弾塑性

\section{表 4 テンションリング強度と重量}

\begin{tabular}{lccccc}
\multicolumn{1}{c}{ Model } & $w_{c r}^{r l .0}$ & $w_{c r}^{r l .2}$ & $\Delta w_{s(r)} / w_{s}$ & $w_{c r}^{r l .0}$ & $w_{c r}^{r l .2}$ \\
& $/ w_{d}$ & $h_{d}$ & $(\%)$ & $w_{s}^{r l .0}$ & $h^{r l .2}$ \\
\hline C1_20_U & 1.09 & 1.22 & 4.5 & 16.5 & 17.6 \\
C1_20_A05 & 1.14 & 1.29 & 3.0 & 10.2 & 11.2 \\
C1_20_B05 & 1.17 & 1.32 & 2.8 & 10.3 & 11.3 \\
\hline C1_40_U & 1.12 & 1.23 & 2.65 & 9.31 & 9.97 \\
C1_40_A05 & 1.14 & 1.33 & 1.66 & 4.85 & 5.60 \\
C1_40_B05 & 1.17 & 1.31 & 1.61 & 5.53 & 6.09 \\
\hline C2_20_U & 1.12 & 1.22 & 2.7 & 8.82 & 9.17 \\
C2_20_A05 & 1.12 & 1.30 & 3.0 & 5.22 & 5.88 \\
C2_20_B05 & 1.14 & 1.33 & 2.9 & 5.00 & 5.69 \\
\hline C2_40_U & 1.08 & 1.27 & 1.99 & 3.47 & 4.02 \\
C2_40_A05 & 1.11 & 1.30 & 1.28 & 2.06 & 2.39 \\
C2_40_B05 & 1.11 & 1.29 & 1.36 & 2.32 & 2.66 \\
\hline
\end{tabular}
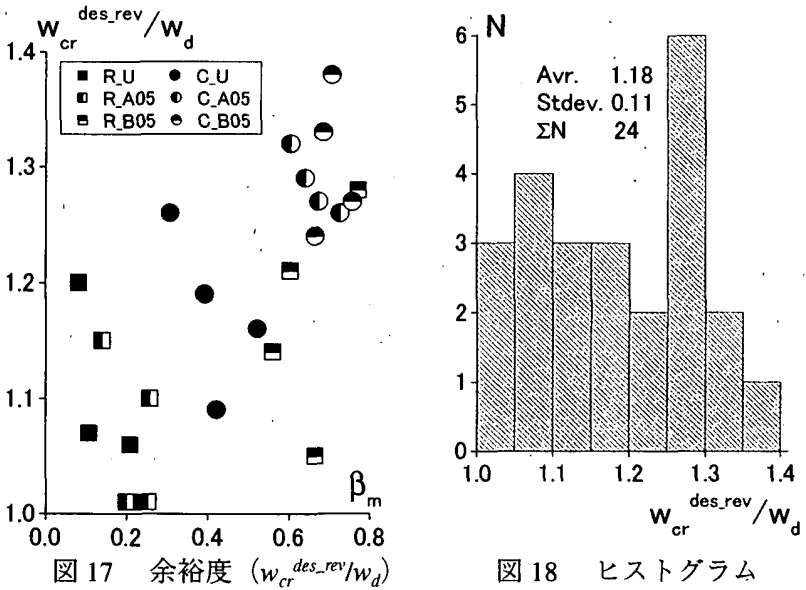

図 18 ヒストグラム

座屈荷重 $w_{c r}^{r_{-} l .2}$ はほほ $w_{c r}$ des 等しい。

弾塑性座屈荷重の単位面積あたりの構造体重量 $w_{s} に$ 対する比を 材料効率の指標と考える。表 4 を見ると、 $\Phi_{r}$ を 1.0 から 1.2 に上げ るときの重量増加率 $\left(\Delta w_{s(r)} / w_{s}\right)$ は数\%であるが、これにより材料効率 は最大で約 14\%改善される。原の值は安全率も考慮したコストと強 度に関する総合的な設計思想から決定すべきであろう。

\section{5.まとめと今後の課題}

以上、偏載荷重を含む終局荷重に対する単層 2 方向格子シェル の断面設計法を提案した。

設計法は「予備解析」「応力解析」「断面設計」の3 段階から構 成される。「予備解析」では、設計された構造物の弾性座屈耐力を確 保するため、シェル部材の断面剛性と弾性座屈荷重の比例関係（式 （10)）に基づき断面積を軸力に比例させた解析モデルを用いて弾性 座屈解析を行い、式(12)より正規化細長比を定める。「応力解析」で は、設計後の断面剛性を式(22)で予測して解析モデルの断面とし、 弾性非線形解析を行って設計荷重下の部材応力を求める。「断面設 計」では、曲げを受ける柱の耐力式(18),(19),(20)に、予備解析で得た 正規化細長比と応力解析で得た部材応力を代入して断面を定める。 以上のプロセスの適用により、シェルとしての座屈と幾何学的非線 形性の影響を考慮し、所要の終局座屈耐力を満足する断面を設計す ることができる。

また、試設計例の数值解析結果は、弾塑性座屈荷重の初期不整 敏感度が曲げモーメントが断面設計に及ほす影響を表すファクター (式(24)にて定義される $\dot{\beta}_{m}$ ) と相関することを示す。解析結果から 等分布荷重を受ける場合と、偏載荷重下で完全形の設計断面につい て $\beta_{m} \leqq 0.3$ となる場合については、予備解析に形状初期不整を考慮 することとした。

テンションリングの設計には特に余裕を見込む必要はないが、 1.2 程度の余裕係数を断面設計時に考慮すれば構造全体の材料効率 が大きく改善される。

なお、当設計法の限界㧍よび今後の主な課題としては以下の点 が考えられる。

1) 通常設計においては複数の荷重の組み合わせを考慮する必要 があるが、当設計法は直接にはこれに対応していない。 
2) 設計法は数值実験（FEM）を用いて検証したが、数值実験は 理想化された構造モデルの数值解析であり、形状初期不整以外 の、材料、施工等の要因による座屈挙動の不確定性は結果に反 映されない。安全率を定める際はこの点を考慮すべきである。

3) 接合部は完全剛接合を仮定したが、接合部の力学的特性が座屈 耐力に及ばす影響は無視できないと考えられる。完全剛接合と みなせない接合部デイテールを探用する場合について、その力 学的特性を定量的に座屈設計に反映する手法の開発が必要で ある。

\section{䀣辞}

（株）巴コーポレーション岡本哲美、久保寺勲両博士、太田鞆 靖氏より、当研究の機会と支援を頂いた。

注 1 ）当論文における「単層 2 万向格子シェル」とは、部材同士が 偏芯せず接合されており、主材以外の補剛材を持たない形式の構造 1),6) 99,15) 18)を意味し、編成式シェル 19)やブレース補剛シェル20)のよ うな構造は当設計法の対象外とする。

注 2 ) 幾何学的及び材料学的非線形性解析を設計に用いた例は極め て少ない 21

\section{補足} 予備解析モデル断面の定め方

当論文の設計例においては、予備解析モデルの断面は以下のプ ロセスで定めた。

(1) 断面の肉厚を一律に $2 \mathrm{~cm}$ とする。

(2) 荷重レベルを $w_{d}$ として線形解析を行う。

(3) 式(11)，(15)を適用して部材軸力に比例する断面を定める。

(4) (2), (3)を 3 回繰り返す。

\section{省考文献}

1) Ban, S., Ito, H., Sasaki, N., Yoshida, A., Higuchi, S. and Onodera, T. (Part I ), Tsubota, H., Yoshikawa, S. and Ikeda, K. (Part II ): Construction of a Dome over an Existing Stadium Part I : Structural Design and Construction Method, Part II: Verification of Structural Safety, Proceedings of the IASS 40th Anniversary Congress edited by Astudillo, R. and Madrid, A., J., Cedex, Madrid, Sept., Vol. II , pp.J1.15 $\sim \mathrm{J} 1.32,1999$

2) Kato, S., Shibata, R., Ueki, T. and Matsushita, F.: Buckling Load Estimation for Single Layer Domes by the Concept of Column Strength Curves, Proceedings of IASS-MSU Symposium, Mimar Sinan Universitesi, Istanbul, pp.507 512, 1993

3) 加藤史郎、高嶋英幸、松永靖二：弾性 2 次解析を用いた単層円筒 ラチスシェルの断面算定法についての一考察、日本建築学会構造 系論文集、第 511 号、pp.107 114、1998.9

4) 加藤史郎、松永靖二、仁保裕：弾性 2 次解析を用いた単層ラチス ドームの断面算定法についての一考察、日本建築学会構造系論文 集、第 526 号、pp.93 100、1999.12

5) 加藤史郎、金鍾敏、仁保裕：偏載荷重を受ける単層ラチスドーム の座屈応力度と座屈荷重に関方る研究、日本建築学会構造系論文 集、第 541 号、pp.121 128、2001.3

6) 加藤史郎、山下哲郎、柴田良一：連続体近似法による 2 方向格子 シェルの座屈耐力評価、構造工学論文集、日本建築学会、Vol.46B、 pp.167 174、2000.3
7) Jung, H., M. and Yamada, M.: Buckling of Rigidly-jointed Single-layer Latticed Domes with Square Network: Theretical and Experimental Basic Study, Proceedings of the third summer colloquium on shell and spacial structures, Taegu, Korea, 1990.8

8) 鄭煥穆、王麗、山田大彦: 四角形ネットワークを持つ単層ラチス ドームの座屈特性に関する研究、学術講演梗概集 (九州)、日本 建築学会、構造 I、No.2618、pp.1235～1236、1989

9) Borri, C. and Hufendiek, H., W.: Geometrically-Nonlinear Behavior of Gridshells, 3rd International Conference of Space Structures, edited by Nooshin, H., Elsevier applied science publishers, London, pp.452 456, 1984

10) 日本建築学会：鎆構造限界状態設計指針·同解説、1998

11) Hisatoku, T., Okamura, K., Soga, Y. and Sahashi, M.: Structural Design and Construction of Large-Scale Single-Layer Latticed Dome of Nagoya Dome, Proceedings of the International Symposium, University of Stuttgart Vol.2, edited by Organizing Committee IASS Symposium Stuttgart 1996, E.Kurz \& Co., Stuttgart, pp.1024 1035, 1996.10

12) 日本建築学会：鉄骨工事標準仕様書 JASS6, 1996

13) 小河利行、桑田真理子: 形状初期不整の分布形状が剛接合単層 ラチスドームの弾塑性座屈荷重に与える影響、日本建築学会構造 系論文集、第 531 号、pp.109 105、2000.5

14) ADINA R\&D, Inc. Theory and modeling guide-ADINA, ARD 01-7, 2001

15) Yamashita, T. and Kato, S.: Ultimate Strength Design of Two-way Grid Shells of Single Layer under Gravity Load, Proceedings of ICSCS'01, Pusan, Korea, Vol.1, pp.149 156, 2001.6

16) Yamashita, T. and Kato, S.: Elastic buckling characteristics of twoway grid shells of single-layer and its application in design to evaluate the non-linear behavior and ultimate strength, Journal of Constructional Steel Research, Elsevier Science, Vol.57/12, pp.1289 1308, 2001

17) Matsushita, F., Ohya, T., Mukaiyama, Y. and Matsue, Y.: Study of the Elasto-plastic Buckling of Single-layer Domes, Space structures 4. edited by GA.Parke, Thomas Telford, London, pp. 167 175, 1993

18）山下哲郎、加藤史郎：均一断面 2 方向格子シェルの弾塑性座屈 荷重一柱の設計式を援用した弾塑性座屈荷重の推定一、学術講演 梗概集（東北）、日本建築学会、B-1, pp.893 894、2001

19) Maeno, T., Wada, M., Nagase, T. and Hisatoku, T.: Structural Design and Construction of Timber Lattice Shell, Proceedings of IASS-MSU Symposium, Mimar Sinan Universitesi, Istanbul, pp.479 488, 1993

20) Fujimoto, M., Imai, K., Kushima, S., Kinoshita, R. and Morita, T.: Buckling Design Method of Single Layer Two-way Grid Shells with Diagonal Tension Rod Members -Spherical dome and cylindrical roof-, IASS2001 Extended Abstracts (full-text in CD-ROM), edited by Kunieda, H, Nagoya, Japan, TP088, pp.200 201., 2001.10

21) 日本建築学会：空間構造の耐震設計と設計例, 2001

（2002年 6 月 7 日原稿受理，2002年11月11日採用決定） 